\title{
Biosaintifika
}

Journal of Biology \& Biology Education

http://journal.unnes.ac.id/nju/index.php/biosaintifika

\section{The Potential Fruit Crop of Cibodas Botanical Garden}

\author{
${ }^{\varpi}$ Suluh Normasiwi, Muhammad Imam Surya
}

DOI: 10.15294/biosaintifika.v8i2.5235

Cibodas Botanic Garden, Indonesian Institute of Sciences, Indonesia

\section{History Article}

Received 2 March 2016 Approved 18 July 2016 Published 18 September 2016

\section{Keywords:}

Cibodas Botanical Garden; fruit collections; potential fruit crop

\begin{abstract}
As an institute for ex situ plant conservation of high mountains, Cibodas Botanical Garden (CBG), has more than 1652 species and 8140 specimens of plant collections. An inventory of potential fruit crop in CBG which will support the conservation program had never been done before. The aim of this activity is to determine its potential collections as fruit crop. Descriptive analysis was used to analyze all the data achieved from registration unit and catalogue of (CBG). The results showed that 422 numbers of collections from 31 family, 56 genus and 114 species have high potential as a fruit crop. Moreover, Cibodas Botanical Garden has $74 \%$ collection of indigenous fruit (included 85 species) and 61\% collection of underutilize fruit (included 68 species) from the total number of fruit plant collections. Most of potential plant collections are able to be developed as an edible fruit crop in Indonesia in order to enhance local food security through diversification of fruit crop.
\end{abstract}

\section{How to Cite}

Normasiwi, S., \& Surya, M. I. (2016). The Potential Fruit Crop of Cibodas Botanical Garden. Biosaintifika: Journal of Biology \& Biology Education, 8(2), 206-213.

(C) 2016 Semarang State University
Correspondence Author:

Kebun Raya Cibodas, Sindanglaya

PO. Box 19 Cipanas-Cianjur, West Java 43253, Indonesia

E-mail: snsuluhsiwi10@gmail.com
p-ISSN 2085-191X

e-ISSN 2338-7610 


\section{INTRODUCTION}

Indonesia is one country with having a very high biodiversity; BAPPENAS (2003) reported that there are at least 38.000 species of plants with $55 \%$ of them are endemic from (of) Indonesia. It makes Indonesia as a unique natural laboratory of tropical plants (Purnomo et al., 2014). The natural of tropical rainforest which have high humidity, rainfall, and sunlight intensity makes it favorable for many plants to get optimum growth (Murdjoko et al., 2016). Biodiversity of Indonesia was also includes a diversity of tropical fruits. Waluyo (2011) reported that there are at least 592 accessions of fruits crops genetic resources were collected in Indonesian Agency for Research and Development, Ministry of Agriculture. However, there is only 95 out of 592 numbers of accessions that have been studied.

Genetic diversity of indigenous fruits of Indonesia is very high, and it is important to developed as and fruits crops. In spite of this, the research activity of Indonesian native fruits is very rare. In the other hand, the utilization and cultivation of indigenous fruits were very limited. Indigenous knowledge of wild edible plant is important for sustaining utilization of those plant species (Jasmine et al., 2007). Fruit breeding is an important program to improve the quality and productivity of indigenous fruits, in order to diversify the edible fruits of Indonesia (Uji, 2007a).

Cibodas Botanical Garden (CBG) is a worldwide nature reserve area which is included in the Cibodas Biosphere Reserve. It is located at the lower side of Mount Gede Pangrango, Cianjur, West Java, with an altitude of 1300-1450 meters above the sea level, air temperature of $18-20$ ${ }^{\circ} \mathrm{C}$, and the humidity of $90 \%$. The spesification of environment make $\mathrm{CBG}$ as the wettest regions in West Java. CBG has duties and functions such as conservation, research, environmental education, tourism, and environmental services. Currently, CBG has collected 1652 species and 8140 specimens of plants as garden collections (CBG data registration unit December 2014). CBG collections consist of indigenous plant, exotic plants, and it came from exchange seed (such as Europe, Australia and Asia) and exploration of mountain forest in Indonesia. Among these collections consist of edible fruit plants or potential fruit crop plants, especially plants of highland region.

$\mathrm{CBG}$ as an ex situ plant conservation institution have to promote a potential collection. An inventory of potential fruit crop in CBG which will support the conservation program had never been done before. It give an effort to provide base line data that can be helpful in ensuring sustainable potential fruit crop of CBG collection. This study aimed to invent and determine-potential collections as fruits crops in the domestication program.

\section{METHODS}

The research has been done on potential plant collections which are potential for becoming fruit crops. The activities were started by field observation in the garden to determine some potential plants located in the CBG collection and continue by verifying the potential plant collection with the data on the catalogue book "List of Living Plant Collection Cultivated in Cibodas Botanic Garden" and website http://siregist.krcibodas.lipi.go.id from registration unit. This study used CBG living collections data up to the end of 2014, since there is no recent comprehensive up date to the data. Data included name of species, family, habitus, origin, distribution, and the number of living the collections were summarized. The information related to potential fruit was obtained by literacy studied.

The plant collections in CBG, which had major (primary used as fruit crop) and minor (have other benefits besides fruits) functions as edible fruit, were used in the analysis (Verheij \& Coronel, 1992). In other hand, the species with hard-skinned fruits or fruit with a hard dry pericarp or shell (nut) had not been put into potential species for fruit crops on this study (Uji, 2007b). Moreover, a descriptive analysis by Walpole (1995) was conducted to provide information and summarize the data.

\section{RESULTS AND DISCUSSION}

Based on the observations and analysis of CBG collections, CBG has high potential fruit collections that can be developed as fruit crops. Up to the end of 2014, there were 422 fruit crop collections which consist of 31 family, 56 genera and 114 species. Fig 1 shows the families distribution of fruit crop collections in CBG. The results show that this collection mostly came from the families of Rosaceae (16 species) and Myrtaceae (16 species), followed by families of Moraceae (12 species), Phyllanthaceae (10 species) and Meliaceae (7 species).

\section{Rosaceae}

Rosaceae is one of the largest fruit family that high potential to be develop into fruit crops in CBG. Moreover, the results showed that there 


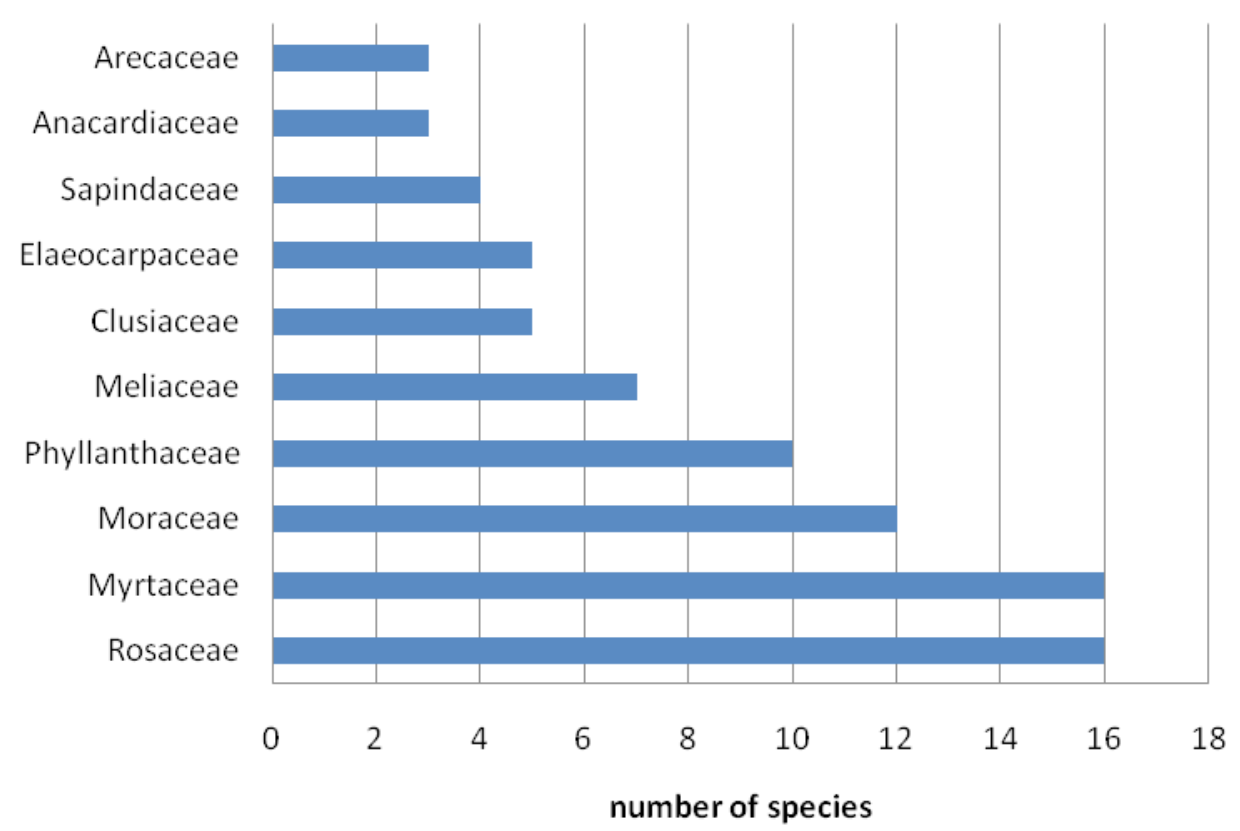

Figure 1. Family distribution of Fruit Crop Collections in CBG

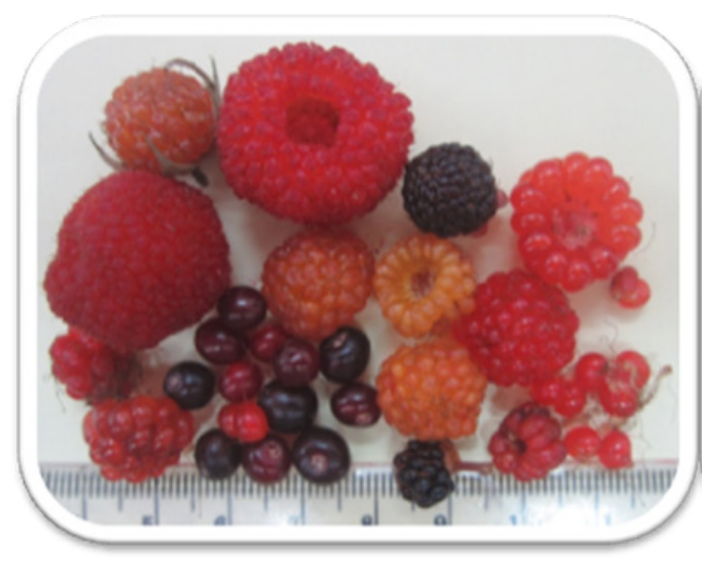

a

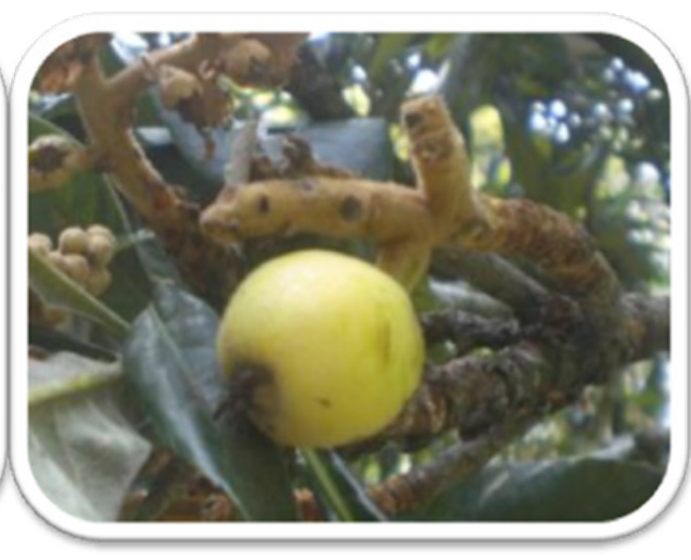

b

Figure 2. Fruits of Rosaceae Family in CBG (a) wild raspberry (Rubus spp.) (b) loquat / papalaan (Eriobotrya japonica)

are 6 potential genera as fruit crops, i.e Eriobotrya, Malus, Prunus, Pyracantha, Pyrus, Rubus. Rubus and Eriobotrya were the genera that have a very high potential to be developed as a fruit crops but they have not been utilized yet.

On 2015, Surya et al. (2015) reported that CBG has 12 species of Rubus (R. acuminatissimus, $R$. alceifolius, $R$. alpestris, $R$. chrysophyllus, $R$. ellipticus, $R$. elongatus, $R$. fraxinifolius, $R$. lineatus, $R$. moluccanus, $R$. pyrifolius. $R$. rosifolius, Rubus $\mathrm{sp}$ ) that were collected from Indonesian mountain forests. Rubus, also known as wild raspberries (Figure 2.a), is highly potential fresh fruits, beverage raw materials and medicinal plants.
Eriobotrya japonica was distributed from Himalaya region to Japan and throughout Southeast Asia went southwords to Sumatera, Malaya, and Borneo (Kalkman, 1993). In Indonesia, $E$. japonica has been used as ornamental plant in highland (Verheij, 1992). E. japonica often called loquat or papalaan (Sundanese) could be eaten as fresh fruit, salads, and also commonly use as row material for jam, jelly and chutney. The fruit was similar to-apples in many aspects, with high sugar, acid and pectin content (Facciola, 1990). In the other hand, the collections from genera Malus and Pyrus which is a family of apples and pears, never bear any fruit since its planting in CBG. 


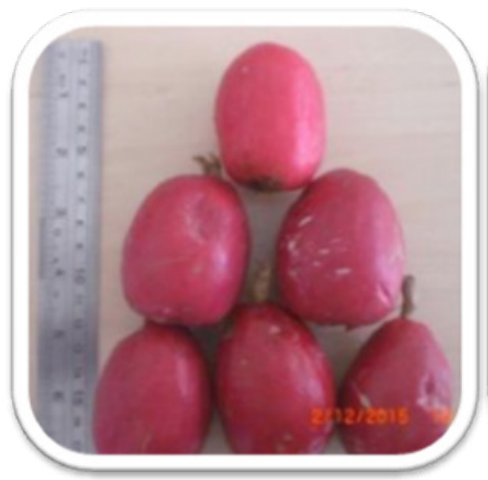

a

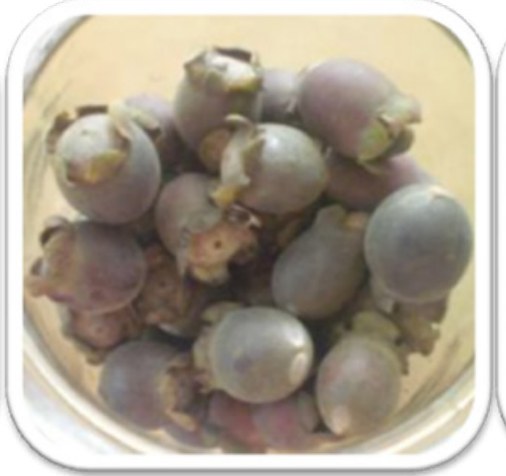

b

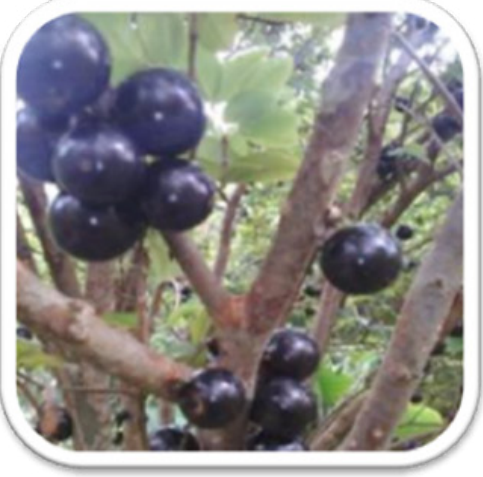

c

Figure 3. Fruit of Myrtaceae family in CBG (a) Syzygium sp (Jambu papua), (b) Rhodomyrtus tomentosa (Kemunting) (C) Plinia cauliflora (Jaboticaba)

\section{Myrtaceae}

In CBG, Myrtaceae is a family with high number of fruit collections other than Rosaceae. Syzygium spp., Psidium spp. and Eugenia sp., belong to Myrtaceae, are a genus with high number of species in CBG. Family of Myrtaceae was divided into two subspecies, i.e. Leptospermoidieae and Myrtoideae. Reynertson et al. (2005) reported that subfamily Myrtoideae such as Syzygium, Psidium, Eugenia, Myrciaria, Plinia, Catinga and Calycorectes has a high potential to be developed as commercial fruit. There are about 500 species of Syzygium that were distribute in tropical and subtropical regions. In Indonesia, Syzygium has been spread and naturalized in almost all areas, from lowland up to 1200 meters above sea level (Verheij \& Coronel, 1992).

Syzygium malaccense, Syzygium polyanthum, and Syzygium jambos are several collections in CBG that are originating from Indonesian mountain forests. S. malaccense is one of Indonesia original species. S. malaccense known as "jambu bol" is native to Southeast Asia, restricted to Java, Sumatra and Peninsular Malaysia, and naturalized in the United States and South America. The fruits of "jambu bol" are red with streaks of pink or white; thick flesh, rather dry and fragrant, but often savorless (Panggabean, 1992). In addition, CBG has Syzygium sp. which is refer to "Jambu Papua". The collection of Syzygium sp. was obtained during exploration program to Papua on 1992. Syzygium sp. or Jambu Papua is potential to be developed as fruit crops. It has good shape and size as fresh fruit but sour taste (Fig. 3.a). Although it has sour taste, CBG proceed it as sweet meat. Rhodomyrtus tomentosa (Figure 3.b) or "kemunting" belongs to Myrtaceae that also has potential as fruit crops. These plants with a wide range of agro-climatic which is ranging from the coast to an altitude of 2400 meters abo- ve sea level, have purple-black fruit, juicy, and sweet taste while mature (Aman, 2002). One species of Myrtaceae collection fruit plant which has economic value is Plinia cauliflora (Jabuticaba) (Figure 3.c). This fruit is known as "Jaboticaba / Brazilian grape" with shapes and black color like wine. In Brazil, jabuticaba's are largely eaten fresh; their popularity has been likened to that of grapes in the United States. Fresh fruit may begin to ferment 3 to 4 days after harvest, so they are often used to make jams, tarts, strong wines, and liqueurs.

\section{Moraceae}

Moraceae, third majority fruit plant collections in the CBG, has the potential to be developed as fruit crops. There were genus Ficus and Artocarpus. In Indonesia, Ficus reached 252 species or about $68.66 \%$ from total number of species in Malesia region. Ficus were spread in almost all of Indonesian islands from the lowland to lower mountain $(<1500$ meters above sea level), and some species were found in the mountainous area between 1500-2500 meters above sea level (Yusuf, 2011). CBG has 6 species of Ficus i.e. F. fistulosa, F. hirta, F. lepicarpa, F. sinuata, F. variegata and F. Carica, that potentially able to be developed as fruits crop. Artocarpus is a native plant of Southeast Asia and commonly grown in Malaysia and Indonesia. Artocarpus has aggregate fruits that can be eaten, either as fresh or processed fruits. CBG has Artocarpus (A.altilis, A.champeden, and A.heterophyllus) that have already been used as fruit crops. Moreover, Figure 4 showing some fruits from family of Moraceae in CBG.

Referring to Figure 1, there were three genera which had high economic value such as Garcinia spp. (Mangosteen) from Clusiaceae, Mangifera spp. (Mango) from Anacardiaceae, and 


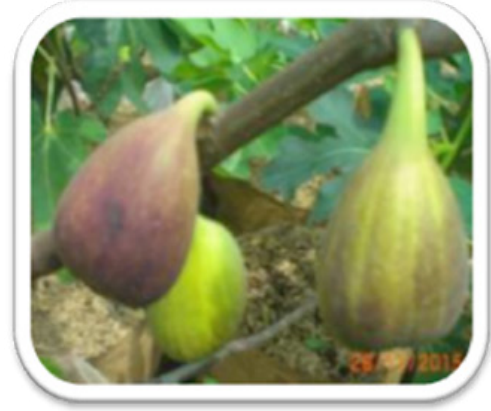

a

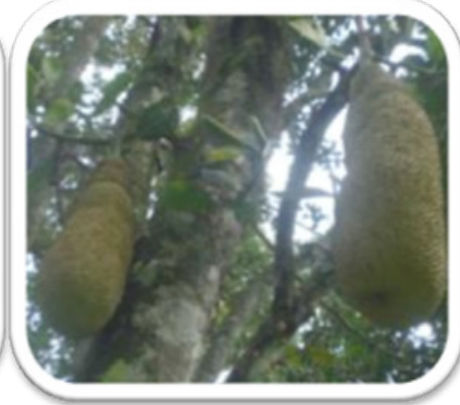

b

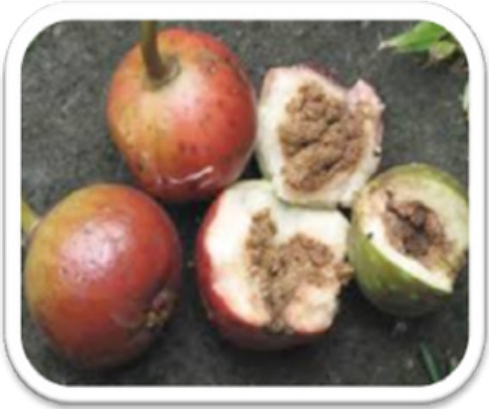

C

Figure 4. Fruit of Moraceae family in CBG (a) Ficus carica (buah Tin); (b) Artocarpus heterophyllus (Jackfruit); (c) Ficus variegata (Kondang)

Nephelium spp. (Rambutan) from Sapindaceae. Moreover, these groups belong to national priority fruits (Winarno, 2000; Uji, 2007)

The other plant collections that have economic potential to be cultivated are Antidesma bunius (buah wuni) and Baccaurea racemosa (menteng) which derive from the family of Phyllantaceae; Aglaia eliptica and Aglaia edulis (langsat) which derive from the family of Meliaceae; Elaeocarpus angustifolius (ganitu) which derive from the family of Elaeocarpaceae; and Salacca zalacca (salak) which derive from the family of Arecaceae.

Antidesma bunius (buah wuni) fruits have been used as a raw material for making tasty jelly jam, drinking juice and juice concentrate, in other hand A.bunius fruits traditionally used as a medicinal plant for gastric intestinal problem (Butkhup \& Samappito, 2008). Baccaurea racemo$s a$ (menteng) is under-storey, evergreen, perennial tree reaching $15-20 \mathrm{~m}$ tall, it has an edible fresh stewed arillode, pickled, fermented or made into drinks (Lim, 2012). Although Salacca is able to be found in West Java and South Sumatera, its origin is still unclear (Uji et al., 1998; Uji, 2007). Several methods of fruit use have also been recorded. Ripe fruits are mostly eaten raw whereas unripe fruits are used variedly and cooked as vegetable, mixed with curry, eaten with salt and cooked with dry fish (Jeeva, 2009).

Local fruits mean Indonesian indigenous fruits and naturalized an exotic fruits that are found in Indonesia (Rifai, 1986). Verheij \& Cornell (1992) reported that there are 400 species of edible fruits in Southeast Asia. Futhermore, Uji (2004) also recorded that there are 226 species of Borneo indigenous fruits that were able to be used as fruit germplasm, In the other hand, Siregar (2006) reported that there are 130 species of local fruits (indigenous or exotic) that have been consumed by the local people in Borneo.
Uji (2007) reported that more than $75 \%$ of wild fruits in South East Asia were found in Indonesia. Furthermore, based on his data there was 266 species of Indonesian indigenous fruits (included 4 subspesies and 2 varieties) that grew wildly and uncultivated yet.

A comparison of total fruit collections in CBG between exotic and local fruits show that the collections of local fruits $(76 \%)$ was higher than exotic fruits (24\% (Figure 5). Moreover, referring to the data of Uji (2007), CBG has been able to collected 85 species out of 266 species of Indonesian indigenous fruits. It was quite far from total species target, due to CBG focus on high-mountain plant conservation. Although, CBG has some species from low land, but most of them were not able to produce a good fruits. It might be due to the temperature and rainfall in $\mathrm{CBG}$.

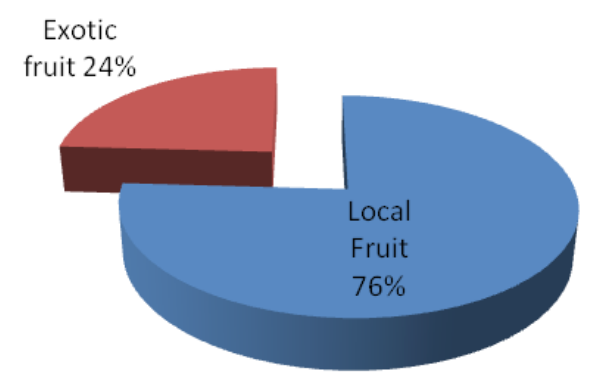

Figure 5. Comparison of exotic and local fruit collections in CBG

Futhermore, comparison of wild fruits and cultivated fruits in CBG show that $61 \%$ the potential fruits collections in CBG were not utilize yet (Fig.6). Unfortunately, the majority of cultivated fruits were exotic fruits. It means that a fruits collection in CBG has high opportunity to be developed as an alternative fruit crops in Indonesia. 
Table 1. The collection of local fruits in Cibodas Botanic Garden

\begin{tabular}{|c|c|c|c|}
\hline Family & Species & Indonesian Local Name & Origin \\
\hline \multirow[t]{3}{*}{ Anacardiaceae } & Mangifera laurina Blume & Mangga pari ; Pelem kecik & Aceh \\
\hline & Mangifera odorata Griff. & Mangga kweni & Java, Jambi \\
\hline & Mangifera similis Blume. & Asem rawa & Aceh \\
\hline Arecaceae & Salacca zalacca (Gaertn.) Voss & Salak & Jambi \\
\hline \multirow[t]{4}{*}{ Clusiaceae } & Garcinia beccari Pierre & Burita & Aceh \\
\hline & Garcinia dulcis Pierre & Mundu & Aceh \\
\hline & Garcinia mangostana $\mathrm{L}$. & Manggis & Aceh \\
\hline & Garcinia parviflora Benth. & Kemenjing, Kandis & Aceh \\
\hline Ericaceae & $\begin{array}{l}\text { Vaccinium varingiaefolium } \\
\text { (Blume) Miq. }\end{array}$ & $\begin{array}{l}\text { Kicak-kicak, Cantigi } \\
\text { ungu, Manis rejo }\end{array}$ & W. Java \\
\hline \multirow[t]{2}{*}{ Malvaceae } & Durio kutejensis (Hassk.) Becc. & Lai & Borneo \\
\hline & $\begin{array}{l}\text { Durio zibethinus Rumph. ex Mur- } \\
\text { ray }\end{array}$ & Durian & Bengkulu \\
\hline $\begin{array}{l}\text { Melastomata- } \\
\text { ceae }\end{array}$ & Melastoma malabathricum L. & Senduduk & W. Java \\
\hline \multirow[t]{2}{*}{ Moraceae } & $\begin{array}{l}\text { Artocarpus altilis (Parkinson) } \\
\text { Fosberg }\end{array}$ & Sukun & Papua \\
\hline & Artocarpus champeden Stokes & Cempedak & \\
\hline Musaceae & Musa acuminata L. & Pisang & W. Java \\
\hline \multirow[t]{4}{*}{ Myrtaceae } & Syzygium cumini (L.) Skeels & Jamblang, Duwet & Java \\
\hline & Syzygium jambos (L.) Alston & Jambu mawar & \\
\hline & $\begin{array}{l}\text { Syzygium malaccense (L.) Merr \& } \\
\text { L.M.Perry }\end{array}$ & Jambu bol & Jambi \\
\hline & $\begin{array}{l}\text { Syzygium polyanthum (Wight) } \\
\text { Walp. }\end{array}$ & Daun salam & W. Java : Cibodas \\
\hline \multirow[t]{2}{*}{ Pandanaceae } & Pandanus conoideus Lam. & Buah merah & Papua : Wamena \\
\hline & Pandanus dubius Spreng. & Pandan seran & Papua \\
\hline \multirow[t]{3}{*}{ Phyllanthaceae } & Antidesma bunius (L.) Spreng. & Buni, Wuni & Indonesia \\
\hline & $\begin{array}{l}\text { Baccaurea motleyana (Müll.Arg.) } \\
\text { Müll.Arg. }\end{array}$ & Rambai & Indonesia \\
\hline & $\begin{array}{l}\text { Baccaurea racemosa (Reinw. ex } \\
\text { Blume) Müll.Arg. }\end{array}$ & Kepundung, Menteng & Indonesia \\
\hline \multirow[t]{2}{*}{ Rosaceae } & Rubus fraxinifolius Poir. & Arben & W. Java : Cibodas \\
\hline & Rubus rosifolius Sm. & Bereretean, Sabit & \\
\hline Salicaceae & Flacourtia rukam Zoll. \& Moritzi & Ganda rukem & Java \\
\hline \multirow[t]{2}{*}{ Sapindaceae } & $\begin{array}{l}\text { Mischocarpus pentapetalus (Roxb.) } \\
\text { Radlk. }\end{array}$ & Rambutan pucat & W. Java , C. Java \\
\hline & $\begin{array}{l}\text { Pometia pinnata J.R.Forst. \& } \\
\text { G.Forst. }\end{array}$ & Matoa & Papua \\
\hline Sapotaceae & Mimusops elengi $\mathrm{L}$. & Tanjung & Jambi \\
\hline \multirow[t]{2}{*}{ Zingiberaceae } & Etlingera elatior (Jack.) R.M.Sm. & Honje, Kecombrang & Aceh \\
\hline & Etlingera solaris (Blume) R.M.Sm. & Honje Warak, Tepus & Aceh \\
\hline
\end{tabular}




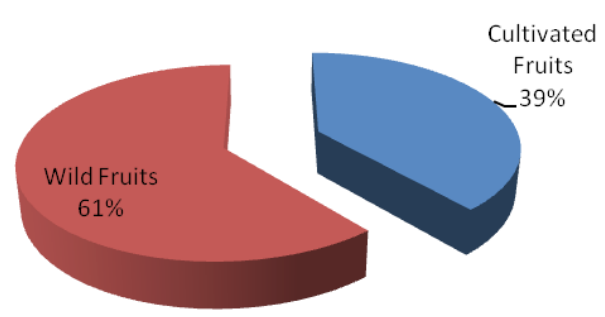

Figure 6. Comparison of wild and cultivated fruits in $\mathrm{CBG}$

Yosini (2011) reported that the Indonesian people would like to buy imported fruits than local fruits. It was probably due to the regulation of government and the price of imported fruits was cheaper than local production. Furthermore, apples, citrus and mango were the favorite fruits for consumption of Indonesian people. The magnitude of import fruits made the market was dominance by import fruits. So many things are being considered by consumers to buy the fruits. The limitation of fruits quality and production made the local farmer has low competitiveness than the import one.

Utilization and development of wild fruits is important to support food security by fruit diversification. Plant genetic resources and plant diversity of wild fruits is an asset for breeding program. Unfortunately, most of wild fruits belong to trees. It needs a good strategy of breeding methods to utilize and developing several wild fruits such as Rubus spp., Syzygium spp., Sorbus sp. and Rhodomyrtus sp, through domestication program.

\section{CONCLUSIONS}

Cibodas Botanical Garden had high potential of plant collections from Indonesian mountain forests to be developed as fruit crops. Currently, CBG had more than 400 numbers of fruit collections from wild species that able to be used in domestication program. The best strategy of domestication program-to utilize and develop these resources its able to transform the consumers perspective of local fruits. It would be in line with national program of food security through diversification of fruit crops.

\section{ACKNOWLEDGEMENT}

The authors would like thanks to registration unit of Cibodas Botanical Garden that has already supported this study.

\section{REFERENCES}

Aman, R. (2002). Buah-buahan Malaysia. Selangor Malaysia: Dewan Bahasa dan Pustaka.

Bappenas. (2003). Indonesian Biodiversity Strategy and Action Plan. Dokumen Nasional. Jakarta: Bappenas.

Butkhup, L. \& Samappito, S. (2008). An Analysis on Flavonoids Contents in Mao Luang Fruits of Fifteen Cultivars (Antidesma bunius), Growth in Norhteast Thailand. Pakistan Journal of Biological Sciences. 11(7), 996-1002.

Facciola, S. (1990). Cornucopia: a Source Book of Edible Plants. Malaysia: Kampong Publications.

Jasmine, T. S., Jeeva, S., Fabreena, G. L., Mishra, B. P., Laloo, R. C. (2007). Wild edible plants of Meghalaya, North-east India. National Production Radiance. 6(5), 410-426.

Jeeva, S. (2009). Horticultural potential of wild edible fruits used by the Khasi tribes of Meghalaya. Journal of Agriculture and Forestry. 1(9), 182-192.

Kalkman, C. (1993). Rosaceae. In Flora Malesiana. 11, 227-351.

Lim, T. K. (2012). Edible Medicinal and Non-Medicinal Plant. Volume 4, Fruits. New York: Springer.

Murdjoko, A., Marsono, D., Sadono, R., \& Hadisusanto, S. (2016). Plant species composition and their conspecific association in natural tropical rainforest, South Papua. Biosaintifika: Journal of Biology \& Biology Education. 8(1), 33-47.

Panggabean, G. (1992). Syzygium aqueum (Burm.f.) Alston, Syzygium malaccense (L.) Merr \& Perry, Syzygium samarangense (Blume) Merr \& Perry. In Prosea. Editor: E. W. M. Verheij \& R. E. Coronel. Bogor.

Purnomo, L., Hakim, B., \& Yanuwidiadi. (2014). Eksplorasi tumbuhan buah-buahan khas dataran tinggi Desa Ngadas Kecamatan Poncokusumo Kabupaten Malang. Jurnal Aktual. 2(1), 50-54.

Reynertson, K. A., Basile, M.J., \& Kennelly, E. J. (2005). Antioxidant Potential of Seven Myrtaceous Fruits. Etnobotany Research \& Applications, 3, 25-35

Rifai, M. A. (1986). Flora Buah-buahan Indonesia. Bogor: LBN-LIPI.

Siregar, M. (2006). Species Diversity of Local Fruits Trees in Kalimantan: Problems of Conservation and its Development. Biodiversitas. 7(1), 94-99.

Surya, M. I., Ismaini, L., \& Destri. (2015). Keragaman Buah Raspberries (Rubus spp.) Asal Indonesia. Prosiding Seminar Nasional Biologi Tahun 2014. Universitas Negeri Semarang. pp. 296-305

Uji, T., Siregar, M., Sunaryo \& Somaatmadja, G. (1998). Buah-buahan Bengkulu. Proyek Penelitian, Pengembangan dan Pendayagunaan Potensi Wilayah. Bogor: Pusat Penelitian dan Pengembangan Biologi, LIPI,

Uji, T. (2004). Keanekaragaman jenis, plasma nutfah, dan potensi buah-buahan asli Kalimantan. BioSmart. 6(2), 117-125.

Uji, T. (2007a). Keanekaragaman, persebaran dan potensi 
Suluh Normasiwi \& Muhammad Imam Surya / Biosaintifika 8 (2) (2016) 206-213

jenis-jenis Garcinia di Indonesia. Berkala Penelitian Hayati, 12(2), 129-135.

Uji, T. (2007b). Review: Keanekaragaman Jenis BuahBuahan Asli Indonesia dan Potensinya. Biodiversitas. 8(2), 157-165.

Verheij, V. W. M., \& Coronel, R. E(1992). Plant Resources of South-East Asia (PROSEA) 2: Edible fruits and nuts. Bogor: Prosea foundation.

Walpole, R. E. (1995). Pengantar Statistika. Jakarta: Gramedia Pustaka Utama.

Walujo, E. B. (2011). Keanekaragaman Hayati Untuk Pangan. Makalah KIPNAS X. Disampaikan pada konggres Ilmu Pengetahuan Nasional X, Jakarta 8-10 Nopember 2011.
Winarno. (2000). Kebijakan pemerintah dalam pengembangan hortikultura Indonesia. Prosiding Seminar Sehari. Hari Cinta Puspa dan Satwa Nasional. Menggali potensi dan meningkatkan prospek tanaman hortikultura menuju ketahanan pangan. Pusat Konservasi Tumbuhan. Kebun Raya Bogor: 9-15.

Yosini, D. (2011). Consumer preferences on import and local fruit in Indonesia. Universitatea de Ştiinţe Agricole şi Medicină Veterinară Iaşi - seria Agronomie, Lucrări ştiințifice, 54(2), 32-37

Yusuf, R. (2011). Sebaran ekologi dan keanekaragaman Ficus spp. di Indonesia. Berkala Penelitian Haya$t i, 5 A, 83-91$. 